\title{
プラスチック片を混合したソイルセメント 改良地盤の支持力特性
}

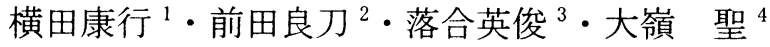 \\ '大分県宇佐土木事務所 ( \\ 2 工博 九州共立大学教授 工学部土木工学科 (テ807-8585 北九州市八幡西区自由が丘 1-8) \\ ${ }^{3}$ 工博 九州大学大学院教授 九州大学大学院工学研究院建設デザイン部門 \\ (下812-8581 福岡市東区箱崎 6-10-1) \\ ${ }^{4}$ 工博 九州大学大学院 九州大学大学院工学研究院建設デザイン部門 \\ （テ812-8581 福岡市東区箱崎 6-10-1）
}

\begin{abstract}
本論文は，ソイルセメント工法に産業廃棄物であるプラスチック片を混合した改良地盤における直接基 礎の支持力特性を明らかにするものである.

ここでは，まず要素レベルの改善効果を明らかにするために一軸圧縮試験を行っている．次に室内模型 装置を用いて直接基礎の支持力実験を行っている。これらの実験の結果，ソイルセメント改良地盤にプラ スチック片を混合した場合, 破壊後のじん性が改善されることが明らかとなった。 また，支持力実験をも とにソイルセメント改良地盤に対する破壊メカニズムを仮定し, 速度場法により支持力評価式を導いた。
\end{abstract}

Key Words: soil cement method, improvement ground, bearing capacity, failure mechanism, velocity field method

\section{1.はじめに}

構造物の基礎は，上部構造物の性能を損なわないよう に十分に安全に支持する役割がある．そのため，地艋の 破壊や変形の影響で構造物の崩壊や使用上の有害な変位 を生じさせないことが重要である.一般に，支持層が深 い場合，杭基礎，ケーソン基礎，地中連続壁基礎などの 深い基礎が採用されてきた。これらの基礎は現在までに 十分な実績があり，さらに安全性や経済性の技術的な検 討もかなり行われているため, 技術的熟度としては既に 成熟した飽和状態にあるといってもよい.

一方，地盤の安定のために軟弱地盤の改良等を目的と して開発された深層混合処理工法や表層のソイルセメン 卜等の地船改良工法は，近年大幅に技術的進歩を続けて いる. この改良地盤は, 一軸圧縮強さ $q_{u} \fallingdotseq 1000 \mathrm{kN} / \mathrm{m}^{2}$ 程 度の強度が比較的容易に得られ，さらに施工管理法の高 度化により, 品質も信頼のおけるものとなりつつある. したがって，今後は構造物基礎の支持地盤として適用可 能性の検討ができる段階にあるといえる.これより，今 後地盤改良により，従来からの媣い基礎が採用されてき
た地艋において直接基礎を採用することにより，建設費 の縮小が図れる可能性がある.

また，近年土に異種材料を混入して土質力学的特性を 改善することを目的とした要素レベルの研究が盛んに行 われている ${ }^{1}$ 。これらはいずれも地盤の有效利用を目的 とした研究であり，これが実用化されることにより，建 設発生土の削堿が期待できる．このなかで，筆者らの一 部 ${ }^{11}$ はセメント安定処理土に加える混合材料としてプラ スチック片に着目した研究を行い，プラスチック片の形 状やセメント添加量が混合処理土の強度変形特性に及ぼ す影響を明らかにしている，廃プラスチックの処理は現 在, 大きな問題となっており, 地盤改良材料としての取 り扱いが可能となれば，産業廃棄物問題にも貢献できる と考えられる. ただし，上述の成果を実務一展開するた めには，要素レベルから地盤の安定解析等を考慮した全 体モデル(マス)の検計が必要である. 改良地盤を構造物 基礎の支持地盤として利用する場合，(1)ぜい性的な破壊 挙動を示す強度变形特性のじん性を改善し支持力信頼性 を向上させ，(2)支持力発現のために必要な改良範囲を確 保する必要がある. 
本研究は, 地盤改良工法の中のソイルセメント工法に 産業廃棄物であるプラスチック片を混合した改良地盤に おける支持力改良効果を明らかにするものである.ここ では，まず，ソイルセメント地盤及びさらにプラスチッ ク片を混合した改良地盤について行われている既往の研 究について紹介し，その要素としての強度変形特性を明 らかにする. ついで, 砂地艋を対象にした室内での支持 力実験を行い，その効果を明らかにした上で, 破壊メカ ニズムを仮定し, 速度場法により支持力式の提案を行い その支持力特性を明らかにする。

\section{2. プラスチック片混合処理土に関する既往の研究}

1.で述べたように, 深層混合処理工法やソイルセメ ント工法等の地般改良工法は, セメント量を調整するこ とにより必要な強度を満足する構造物の支持地盤を作成 することが可能であるが，その一方で強度の増加に伴い ぜい性的な材料に変化する力学特性を有する. この特性 を改善するために, プラスチック片を補強材として混合 した安定処理土について，その強度変形特性を室内実験 により把握する研究がこれまでに行われているいー6).

粘性土を母材とするプラスチック片混合処理土ついて は，一軸圧縮試験，圧裂引張試験および三軸圧縮試験が

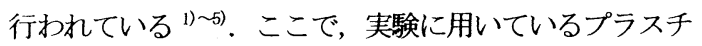
ック片は, 厚さ $0.4 \mathrm{~mm}$, 密度 $138 \mathrm{Mg} / \mathrm{m}^{3}$ の市販のカード ケース用プラスチックシートを長さ $4.8 \mathrm{~mm}$, 幅 $3 \mathrm{~mm}$ に 裁断したものである. 図-1は例としてセメント添加量が $50 \mathrm{~kg} / \mathrm{m}^{3}$ の場合の一軸圧縮試験から得られた圧縮応力一軸 ひずみの関係を示している ${ }^{5)}$. 図中, プラスチック片混 合率 $p$ は，0，2.5，5.0，7.5\%としている.ここで，混合 率 $p$ とは, プラスチック片混合改良地盤全体の体積に占 めるプラスチック片の体積として定義する. これより, プラスチック片を混合した安定処理土のピーク強度が大 きくなっていることと, ピーク強度に達した後にもある 程度の残留強度を保ち, じん性が改善されていることが わかる. また, 圧裂引張試験および三軸圧縮試験結果に ついても同様の傾向を示すことが確認されている ${ }^{2), 3) .}$ なお，強度の改善効果の度合いはセメント添加量などの 影響を受けるものの，いずれの条件においてもプラスチ ック片を混合することでぜい性的な挙動が改善される点 が特長として挙げられる.

一方, 摩擦材料に対する改善効果を検討するために, 砂質土にプラスチック片のみを混合した場合ついて三軸 圧縮試験(CD)が行われている ${ }^{6)}$. 図-2にその例として軸 差応力-軸ひずみ関係を示す.ここではプラスチック片混 合率が $0 ， 1 ， 2 \%$ の 3 ケースを実施している. これより, プラスチック片を混合することで粘性土と同様にピーク

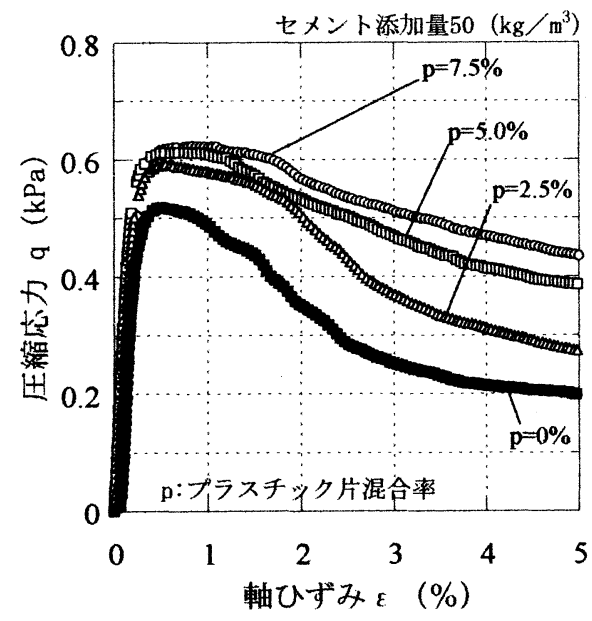

図-1 一軸圧縮試験から得られた圧縮応力ー軸ひずみの関係 (粘性土 $)^{5}$

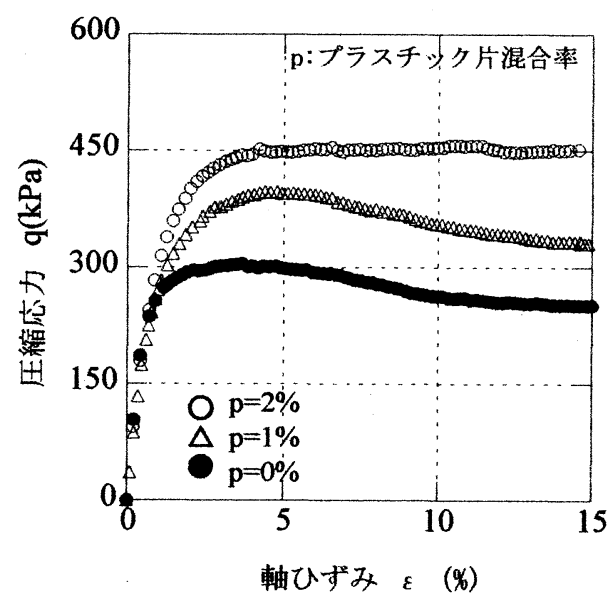

図-2 三軸圧縮試験から得られた軸差忘力一軸ひずみの関釈 $(\text { 砂質士 })^{6)}$

強度以降の強度低下が小さくなっていることがわかる. さらに，プラスチック片混合率が高くなると明確なピー ク強度が現れず，砂質土に対してもプラスチック片を混 合することにより粘り強い材料に変化することがわかる.

以上より，プラスチック片を混合することによって， ぜい性的な挙動を示す地盤材料のじん性が改善される効 果が期待できる.この特性は構造物の支持地盤や軟弱地 盤の表層改良へ適用寸る場合の信頼性に大いに寄与寸る と考えられる.

\section{3. 砂地盤での室内模型支持力実験}

\section{（1）実験装置}

実験は, 図-3に示す実験土槽内に人工的な地盤を作成 


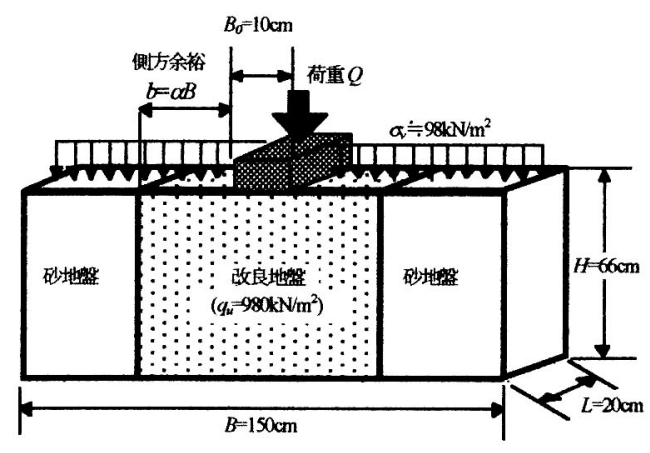

図-3 支持力実験土槽

して行う．土槽は幅 $B_{0}=150 \mathrm{~cm}$ ，奥行き $L=20 \mathrm{~cm}$ ，高さ $H=66 \mathrm{~cm}$ の内空部在有する. 荷重の増大に伴い, 土槽が 横方向に膨らみ出さないようリブで十分な風性を確保し ている.このため，力学的には奥行き方向( $L$ 方向 $へ の$ 変位のないほぼ二次元の応力状態とみなせる. なお，土 槽の側壁は地盤の破壊形状が観察できるように透明のア クリル $(t=15 \mathrm{~cm})$ でできているが，この側壁と地盤の間に 生じる摩擦力を低减するため, ゴムシートを貼り付けて いる．また，地盤に作用する拘束圧を変化できるように 地盤表面にラバーのエアバックを挿入し，空気圧により 上載圧 $\sigma$ 、を作用させる構造となっている. 今回の案験で は，上載圧 $\sigma_{v}=98 \mathrm{kN} / \mathrm{m}^{2}$ としている.

本研究では，改良地盤幅が支持力に与える影響を調べ るため，地盤改良範囲 $w$ を次式で定義している.

$$
w=B+2 b=B(1+2 \alpha)
$$

ここで, $B$ : フーチング幅, $\boldsymbol{b}$ : 側方余裕幅 $(b=\alpha B), \alpha$ : 側方部の改良幅とフーチング幅の比 (改良幅比, $\alpha=b / B$ ), である.

\section{（2） 実験方法}

本研究では，改良地盤としてソイルセメント改良地盤 と，さらにプラスチック片を混合したプラスチック片混 合改良地盤について実験を行う。実験地艋は以下のよう に作成する.

(1)ソイルセメントは，セメント，水，砂をミキサーにて 練り混ぜる. 砂とセメントをミキサー内に入れ 1 分間 練り混ぜた後, 水を注入しその後さらに5 分間練り混 ぜる.

(2)プラスチック片混合改良地盤は，(1)の後：ミキサーを 止め，さらにプラスチック片を混入する。 ミキサーで は混ぜられないので手で練り混ぜるが，プラスチック 片がなるべく均一に混ざるように丁寧に行う.

(3)次に支持力実験土槽内に改良地盤在作成寸る. この之 きも改良地盤が均一になるように慎重に突き固める。 改良地盤の表面を平らにならした後, 濡れタオルで覆
表-1 岡垣砂と豊浦標準砂の物理的特性の比較

\begin{tabular}{|c|c|c|}
\hline & 岡垣砂 & 豊浦標準砂 \\
\hline 土粒子密度, $\rho_{s}\left(\mathrm{~g} / \mathrm{cm}^{3}\right)$ & 2.63 & 2.64 \\
\hline 平均粒径, $D_{S !}(\mathrm{mm})$ & 0.26 & 0.16 \\
\hline 有效粒徍, $D_{l,}(\mathrm{~mm})$ & 0.16 & 0.11 \\
\hline 均等係数, $U \boldsymbol{c}$ & 2.20 & 1.44 \\
\hline 最大間隙比, $e_{\max }$ & 0.93 & 0.98 \\
\hline 最小間䏚比, $e_{\min }$ & 0.56 & 0.61 \\
\hline
\end{tabular}

表-2 ソイルセメント配合表

\begin{tabular}{|c|c|c|c|c|}
\hline \multirow{2}{*}{$\begin{array}{c}\text { セメント水比 } \\
\mathrm{c} / \mathrm{w}(\%)\end{array}$} & \multirow{2}{*}{$\begin{array}{c}\text { 単位セメント量 } \\
\left(\mathrm{kN} / \mathrm{m}^{3}\right)\end{array}$} & \multicolumn{3}{|c|}{ 配合比(重量比) } \\
\hline & & 砂 & セメント & 水 \\
\hline 120 & 2.18 & 6.4 & 12 & 1 \\
\hline
\end{tabular}

い養生する。

(4)非改良部を作成する. 非改良部は岡坦砂で充填する.

改良地盤の型枠を外し，密度が極力一定となるよう空 中落下方式で非改良部老作成する.

実験は，実験地盤作成後，3 日間の養生期間の後，図-3 に示寸ように改良地盤の中央に幅 $10 \mathrm{~cm}$ ，奥行き $20 \mathrm{~cm}$, 質量 $41.7 \mathrm{kN}$ のフーチングを設置し載荷する. 載荷速度は $1 \mathrm{~mm} / \mathrm{min}$ である.このとき, フーチングが接していない 地盤表面にはエアバッグにより上載厂 $\sigma_{v}=98 \mathrm{kN} / \mathrm{m}^{2}$ をか ける. 支持力実験はフーチング幅 $\left(B_{l}=10 \mathrm{~cm}\right)$ の $50 \%$ の変位 $(5 \mathrm{~cm})$ が生じた段階で載荷訆験を終了する.

\section{（3）実験地盤}

\section{a）ソイルセメント改良地盤}

改良地盤のソイルセメントは岡坦砂”と高炉セメント を混合して作成する. 表-1 亿岡垣砂の物理的性質を豊浦 標淮砂と比較して示す。これより，岡垣砂は豊浦標潐砂 と比べてやや粒径が大きいものの均等係数は 220 となつ ており，均一な材料と判定できる.

ソイルセメントの配合は，3 日間の養生後の載荷実験 時において概ね一軸圧縮強さ $q_{u} \fallingdotseq 1000 \mathrm{kN} / \mathrm{m}^{2}$ 程度を目標 としていくつかの配合試験を行い，表-2 に示寸ものを採 用した.

表-3 に作成したソイルセメントの一軸圧縮強さ $q_{u}$ と 砂地船の乾燥密度 $\rho_{t}$ の測定結果走寸。一軸圷縮強さに ついては，支持力実験を行った後で，実験士槽内からサ ンプリングし,整形した供試体について試験したもの(表 中(1)，(2)，および各支持力実験ケースにおいて別途一軸 圧縮試験用として用意した供試体(表中 $3 ， 4 ， 5$ )の計 5 ケース害施している. 表-3 をみると，一軸压縮試験用と して作成した供試体については、ばらつきはあるものの， 概称 $q_{u} \fallingdotseq 1000 \mathrm{kN} / \mathrm{m}^{2}$ は確保されている。一方，実験土槽 内からサンプリングし，整形した供試体について試験し たものから得られる一軸区縮強さは，小さい值を示して いる.これは，いずれの供試体も作成時に均一な密度に なるように体積と投入質量を管理したものの，支持力実 
表-3 実験地盤の力学性状(ソイルセメント改良地盤)

\begin{tabular}{|c|c|c|c|c|c|c|c|c|c|c|}
\hline \multirow{2}{*}{$\begin{array}{l}\text { case } \\
\text { No. }\end{array}$} & \multirow{2}{*}{$\begin{array}{l}\text { 圾験 } \\
\text { 回数 }\end{array}$} & \multirow{2}{*}{$\begin{array}{c}\text { 改良幅 } \\
\text { 比 } \alpha\end{array}$} & \multirow{2}{*}{$\begin{array}{c}\text { プラスチッ } \\
\text { ク片混合率 } \\
p(\%)\end{array}$} & \multicolumn{6}{|c|}{$\begin{array}{c}\text { ソイルセメントの一軸圧縮強さ (3 日後) } \\
q_{u}\left(\mathrm{kN} / \mathrm{m}^{2}\right)\end{array}$} & \multirow{2}{*}{$\begin{array}{c}\text { 砂の密度 } \rho_{d} \\
\left(\mathrm{~g} / \mathrm{cm}^{3}\right)\end{array}$} \\
\hline & & & & (1) & (2) & 3 & 4 & 5 & 平均 & \\
\hline \multirow{3}{*}{0} & 1 & - & 0 & & & & & & & 1.43 \\
\hline & 2 & - & 0 & & & & & & & 1.42 \\
\hline & 3 & - & 0 & & & & & & & 1.41 \\
\hline \multirow{2}{*}{1} & 1 & 0 & 0 & 588 & 823 & 1382 & 627 & 1705 & 1029 & 1.42 \\
\hline & 2 & 0 & 0 & 402 & 382 & 1000 & 1490 & 1098 & 872 & 1.41 \\
\hline \multirow{2}{*}{2} & 1 & 05 & 0 & 598 & 813 & 1558 & 1627 & 1833 & 1284 & 1.42 \\
\hline & 2 & 0.5 & 0 & 774 & 608 & 1029 & 960 & 1382 & 951 & 1.42 \\
\hline \multirow{2}{*}{3} & 1 & 1.0 & 0 & 735 & 794 & 1107 & 990 & 970 & 921 & 1.41 \\
\hline & 2 & 1.0 & 0 & 862 & 902 & 1539 & 1597 & 794 & 1137 & 1.41 \\
\hline \multirow{2}{*}{4} & 1 & 3.0 & 0 & 755 & 647 & 1264 & 1695 & 1196 & 1107 & 1.43 \\
\hline & 2 & 3.0 & 0 & 755 & 539 & 1646 & 1813 & 1597 & 1274 & 1.41 \\
\hline \multirow{2}{*}{5} & 1 & 5.0 & 0 & 951 & 921 & 1607 & 1499 & 1499 & 1294 & 1.41 \\
\hline & 2 & 5.0 & 0 & 676 & 608 & 1000 & 1107 & 1421 & 960 & 1.42 \\
\hline \multirow{2}{*}{6} & 1 & 0 & 5 & 826 & 715 & 1017 & 1024 & 1139 & 1060 & 1.42 \\
\hline & 2 & 0 & 5 & 779 & 816 & 975 & 1026 & 1080 & 1027 & 1.41 \\
\hline \multirow{2}{*}{7} & 1 & 0.5 & 5 & 635 & 701 & 1093 & 1128 & 1076 & 1099 & 1.41 \\
\hline & 2 & 05 & 5 & 754 & 792 & 881 & 916 & 879 & 892 & 1.43 \\
\hline \multirow{2}{*}{8} & 1 & 1.0 & 5 & 953 & 914 & 996 & 1190 & 1105 & 1097 & 1.41 \\
\hline & 2 & 1.0 & 5 & 870 & 852 & 1256 & 1082 & 1101 & 1146 & 1.42 \\
\hline
\end{tabular}

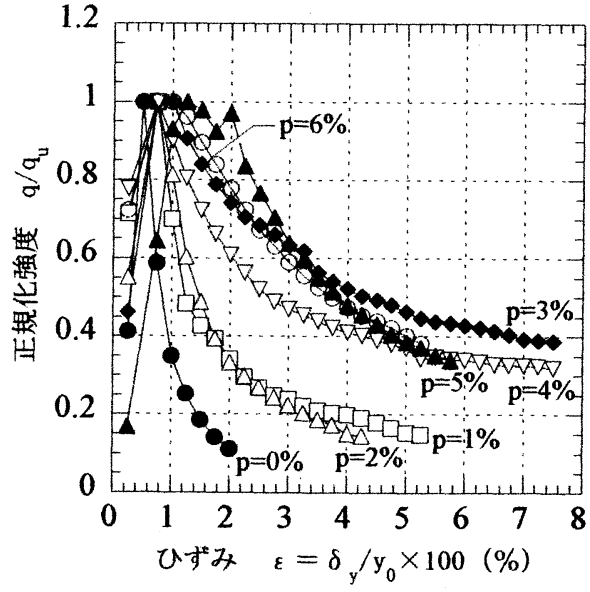

図-4 応力-ひずみ曲線

験土槽は体積が大きく，局所的なばらつきが生じたもの と考えられる. 充分な均一性を持つ実験地盤の作成方法 については今後の検討課題である. また，砂地盤の乾燥 密度についても実験土槽内で 4 箇所計測しているが，各 実験ケースの平均密度は $\rho_{i} \fallingdotseq 1.41 \mathrm{~g} / \mathrm{cm}^{3}$ とどの実験でもほ ぼ同じ結果が得られていることがわかる.

\section{b) プラスチック片混合改良地盤}

本研究で用いるプラスチック片混合改良地盤は，前項 のソイルセメント改良地盤にさらにプラスチック片を混 合したものである. プラスチック片は, 厚さ $0.53 \mathrm{~mm}$, 密度 $138 \mathrm{Mg} / \mathrm{m}^{3}$ の塩ビ版を長さ $48 \mathrm{~mm}$, 幅 $4 \mathrm{~mm}$ にカット したものである.

実験に用いるプラスチック片混合率を決定するため, 予備実験として一軸圧縮試験（供試体径 $D=10 \mathrm{~cm}$ ）を行 った. 試験の供試体は同一日に作成し, 養生 3 日後の試

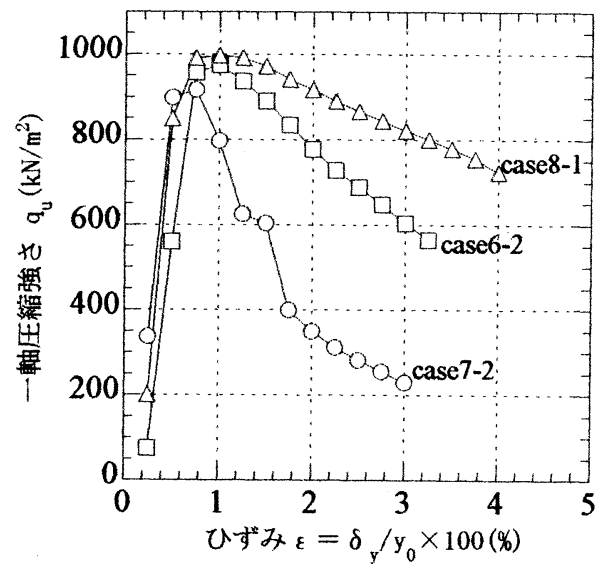

図-5 改良地盤の応力-ひずみ曲線

験に供した. 図-4にその結果を示す. 縦軸は材料のひず み軟化特性を比較するために最大強度 $q_{u}$ で正規化して いる. また，横軸は圧縮量 $\delta$ を供試体高さ $y_{0}$ で除した軸 ひずみをを示している. 試験は同一の混合率 $p$ をそれぞれ 3 ケースずつ行ったが，図-4にはその代表的なものを示 している. 無混合 $(p=0 \%)$ の場合，軸ひずみが $0.5 \%$ 程度 でピーク強度を示し，その後急激に軟化する. プラスチ ック片混合率が增加すると, ピーク強度を過ぎた後の強 度低下が小さくなり，ぜい性的破壊挙動の改善が図られ る. 本試験では, $p=3 \%$ 程度以上となるとその効果が出て いる. そこで, 今回は, 混合率 $p=5 \%$ により改良地盤を 作成することとした.

プラスチック片混合改良地盤は，ソイルセメント改良 地盤同様, 支持力実験時においてその一軸圧縮強さが概 ね $q_{u} \fallingdotseq 1000 \mathrm{kN} / \mathrm{m}^{2}$ になるように, いくつかの予備試験を 


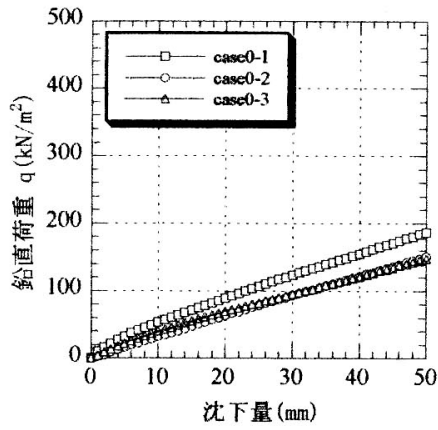

図-6（a）荷重一沈下曲線(case0)

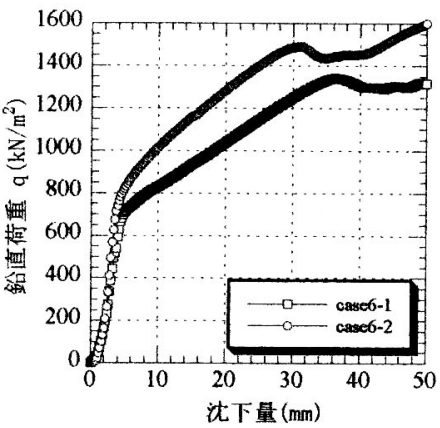

図-6(d) 荷重一沈下曲線(case6)

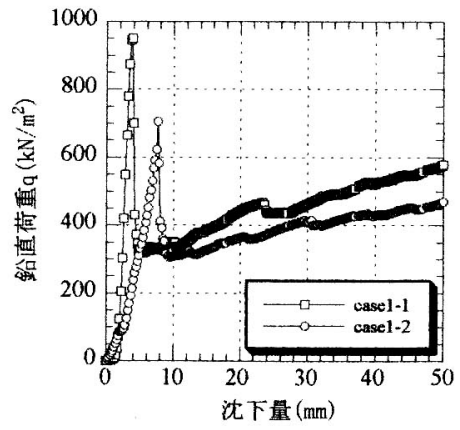

図-6(b) 荷重一沈下曲線(case1)

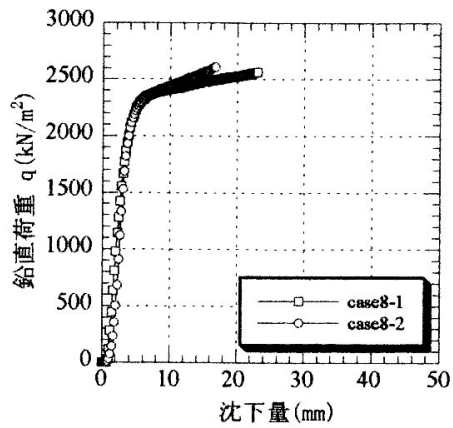

図-6(e) 荷重一沈下曲線(case8)

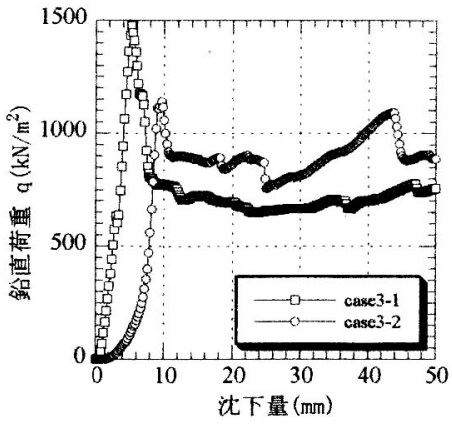

図-6 (c) 荷重一沈下曲線(case3)

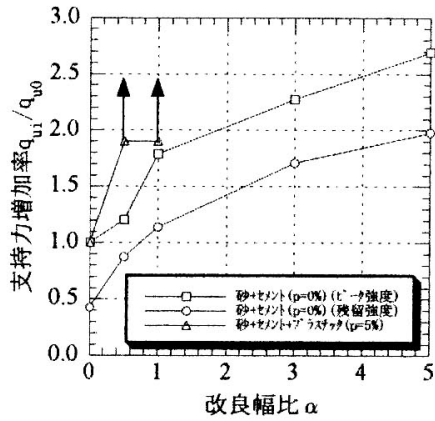

図-7 改良幅比 $\alpha$ と支持力增加率
行い，3 日間の養生期間を設けた。それぞれの試験地盤 において，別途養生した供試体の一軸圧縮強さが目標值 $\left(q_{u} \fallingdotseq 1000 \mathrm{kN} / \mathrm{m}^{2}\right)$ に達した段階で支持力実験を実施した. 表-3に, 3 日後のソイルセメントの一軸圧縮強さと非改 良部の砂の密度を示す。

図-5 は，支持力実験を実施する実験地盤と同時に別途 作成，養生した供試体について，支持力実験を行う直前 に実施した一軸圧縮試験の結果を示したものである．図 -5から得られる改良地盤の強度とひずみの関係は，ピー ク後の岡性は多少ばらつくものの一軸圧縮強さはほぼ同 じであることがわかる.

\section{（4）実験結果}

\section{a) 荷重一沈下関係}

図-6(a)〜 (e) はそれぞれケース 0,1,3,6,8 に対与る荷重 一沈下関係を示している. 図中の凡例は, 例えば「0-1」 はケース0の1回目の実験であることを示している.

図6 (a) は，砂地盤のみの荷重一沈下関係を示している が，計3回の実験結果はほぼ同様の傾向を示しており実 験の精度はかなり高いことがわかる．なお，今回の実験 地盤は原位置での表層部の地盤を想定してゆるい状態と したため，せん断時に砂がダイレタンシーを生じず，荷 重一沈下曲線は明確なピークを示していない.

図-6(b)，(c)の各図はソイルセメント改良地盤に対す

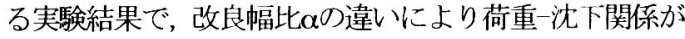
どのように変化するかを示したものである．図-6(a) (砂 地盤のみ) と比較して共通していえることは，荷重一沈下 曲線が明確なピーク值(以降, ピーク支持力) 在示寸こと, また，その後変位の増加に伴って荷重が急激に低下寸る ひずみ軟化現象を示すことである。このひずみ軟化現象 は固結力を有するソイルセメントやせん断時にダイレタ ンシー挙動を示寸非常に締まった士などに見られるぜい 性破壊の特徴をよく表わしているといえる，ただし，い ずれのケースもひずみ軟化に伴って荷重が消失すること はなく，ある一定值まで低下した後，再び増加する傾向 がみられる.また，ピーク支持力以降の荷重の最低值(以 下，残留支持力）も砂地盤のみの場合の支持力に比較して はるかに大きい：これは，上載圧を受けた非改良部地盤 により改良地盤の変形が拘束されたためと考えられれる。 また，図-6(b) と(c) を比較してみると，改良幅比 $\alpha$ が大 きくなるとともにピーク支持力, 残留支持力ともに増加 していることがおかる. なお，各ケースで実験結果にば らつきがみられるが，これはソイルセメントを実験装置 に投入したときに完全に均等には地盤が作成されていな いためと考えられる。

図-6(d)，(e)はプラスチック片混合改良地盤を用いた 支持力実験の荷重一沈下特性を示したものである.

まず，す心゙ての場合において改良地盤において，破壊 
後のじん性が改善されていることが分かる. 沈下量 $\delta_{y} \doteqdot$ $5 \mathrm{~mm}$ で支持力増加率が大幅に小さくなるが，それでも支 持力増加率がマイナスになることはない，これはプラス チック片を混入していない場合と比べて決定的な違いで ある.この場合，变位量が増大しても支持力の低下はな い. すなわち, プラスチック等の混合により, 荷重一沈下 特性を著しく改善することができる.このことは，改良 地盤の支持力信頼性においてきわめて有利となる。つま り，3. で述べる支持力式に用いる強度としてピーク強度 を積極的に用いることができるということになる．さら に，破壊後のじん性が改善できることで，塑性領域にお いても大地震時におけすエネルギ一吸収も期待できる.

\section{b）地盤改良幅が支持力に与える効果}

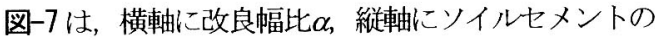
み, およびプラスチック片混入改良地盤の支持力 $q_{u i}$ をそ れぞれの の00ときのピーク強度 $q_{w 0}$ で除した正規化值 $q_{u} / q_{\text {w0 }}$ との関係を示したものである. なお, ソイルセメン トのみの場合はピーク強度が発現した後, 強度が急激に 低下しているため残留強度についても整理している.プ ラスチック混合改良地盤については, 支持力増加は著し いが, 載荷装置の能力の関倸から， $\delta_{y}=50 \mathrm{~mm}$ まで載荷で きなかったので，明確な破壊点を見出すことはできなか った。 そこで，ここでは支持力增加率が大幅に低下寸る $\delta_{y}=5 \mathrm{~mm}$ の時の荷重をピーク強度と考える，なお，実際 の支持力はそれ以上と考えられるため，図中では参考と して上向きの知印を示している.

ソイルセメントのみの場合は, 改良幅比が $\alpha=1.0$ 程度 までは支持力改良効果が著しく，ピーク強度をみると， $\alpha=1.0$ で $\alpha=0$ の場合の約 1.8 倍となっている. 一方， $\alpha か ゙$ 1 以上となると増加の程度はややゆるやかとなる. また， 残留強度についてもピーク強度と同様の傾向が見られる. ただし，図-6からも明らかなように，砂地盤のみの支持 力が約 $200 \mathrm{kN} / \mathrm{m}^{2}(\delta=50 \mathrm{~mm})$ であることを考慮すれば，ピ 一ク強度後の残留強度においても, その改善効果は明ら かである.

プラスチック片混合改良地盤の支持力増加率をソイル セメントのみの場合と比較寸ると， $\alpha<1$ の範囲の結果し かないものの, 支持力增加率はソイルセメントのみの場 合に比べて大きくなっており，プラスチック片の効果が 発揮されていることがわかる. また，表-3から，ソイル セメントのみの場合の一軸土縮強さとプラスチック片混 合改良地盤の一軸圧縮強さとを比較すると, 両者に差は ほぼないことから，プラスチック片が支持力の増加に寄 与していることが分かる.

\section{c）地盤の破壊形状と支持力のメカニズム}

本実験では，フーチング幅 $\left(B_{0}=10 \mathrm{~cm}\right)$ の 50\%の沈下が 生じた段階で穾験を終了し, 両脇の砂地盤を取り除いて, ソイルセメント部に生じているクラックを観察した。さ

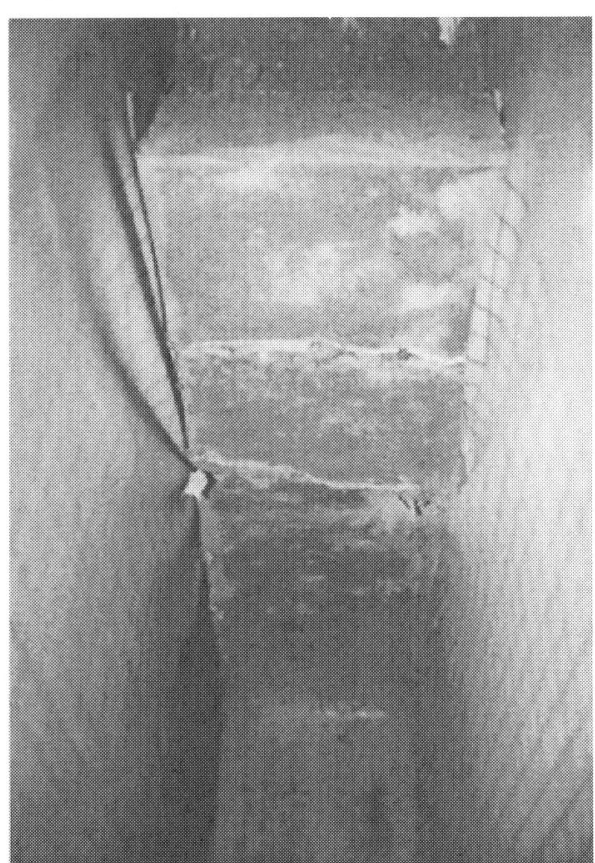

写真-1 側面部すべり面の例(case3-1)

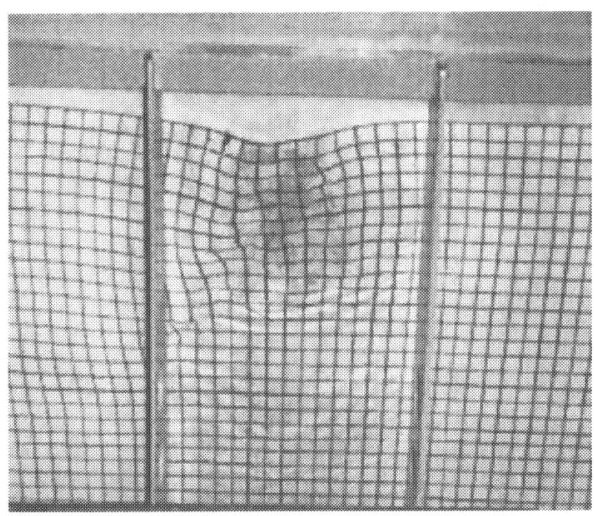

写真-2 ゴムシートの変形から観察されるすべり 面の例 (case3-1)

らに, 摩擦低减のために土槽の側壁の内側に張りつけた ゴムシートの変形から側面側の地盤の破壊形状を推定で きるため, これを組み合わせて全体的な地盤の破壊形状 々支持力のメカニズムを推定する. 写真-1，2 にそれぞ れ側面部すべり面の例とゴムシートから観察されたすべ り面の例老，図-8に推定した破壊形状を示寸。図-8より， 地般の破壊は鈖直荷重に対して, ほぼ左右対称にすべり を生じており，力学的に理想的な形状となっていること がわかる.これは, 両側面からの均一な砂の水平土压が 作用していることによると推定される.ただし，いずれ の場合も砂地盤にはすべり線は観察されなかった。 これ は，砂地盤が改良地盤に比較してゆるく，压縮性が大き 


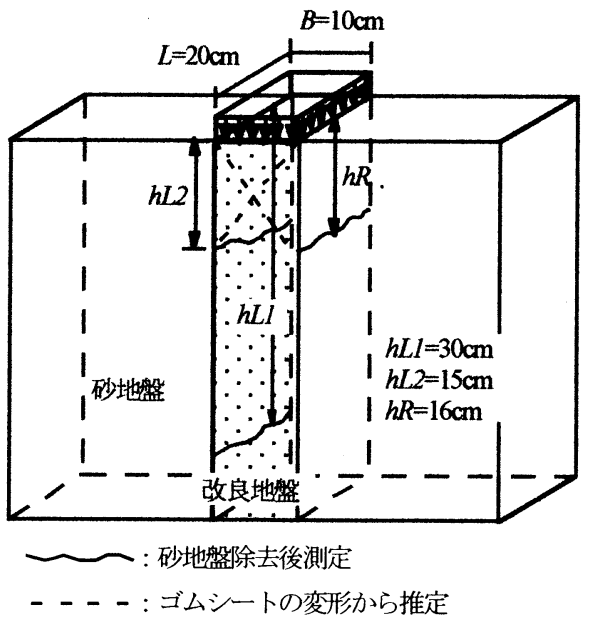

図-8（a）破壊形状(case1)

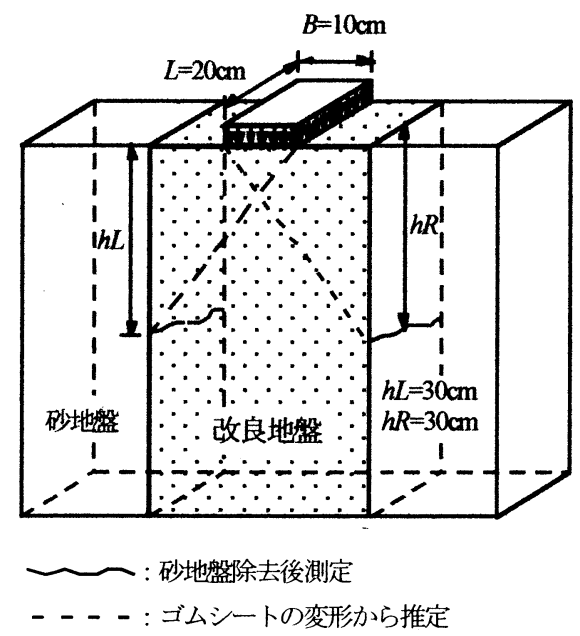

図-8(b) 破壊形状(case3)

いため, 砂地盤にすべりを生じるには変位量が小さいこ とが原因と考えられる.

改良幅比 $の$ 増大に伴い，側面で観察されるひびわれ の位置は深くなっており，このすべり面の拡大により支 持力が増加することが予想できる. また， $\alpha=3, \alpha=5$ で は, 側面のすべり線は確認できなかった. 図一7に示した ように, 改良幅の増加が直線的に支持力の増加につなが るわけではなく, 支持力の増加にも限界がある. すなわ ち, 改良幅の增大に伴いその支持力特性は改良された単 一の改良地般のものへと叹束して行くため, この単一地 盤の支持力が上限となる.

また, ソイルセメントのみの改良地艋に生じるすべり 線とプラスチック片を追加混合した改良地盤に生じるす ベり線との間に破壊形状において大きな差異は見られず, すべり線はほぼ直線となり，プランドルやテルツァギー

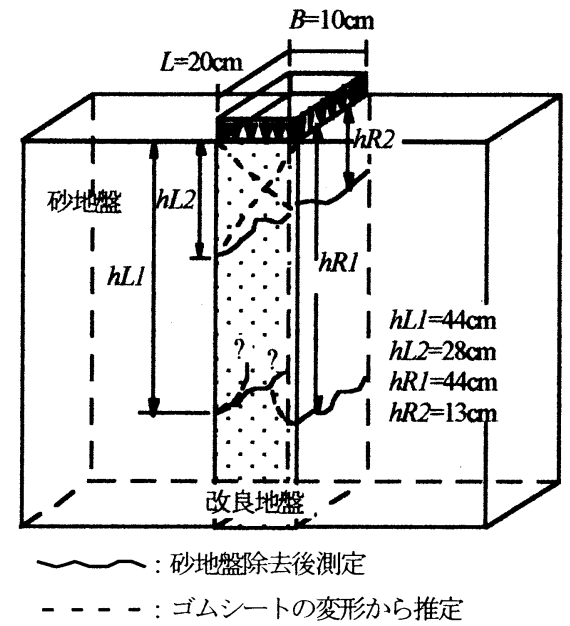

図-8(c) 破壊形状(case6)

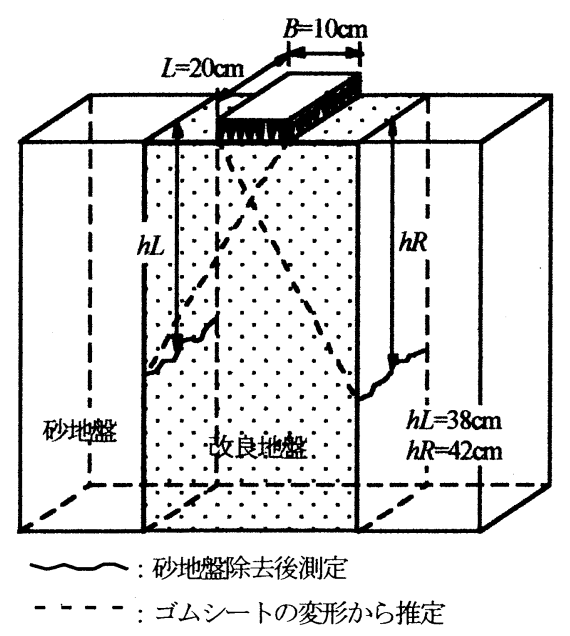

図-8(d) 破壊形状(case8)

の支持力理論による主働領域と受働領域を結ぶ曲線状の 遷移領域が生じていないことがわかる.これは，今回の 室内模型実験では, 改良部の強度や变形に関する力学特 性は実際に適用されるものと同程度のものであるが, 非 改良部の砂地盤は, 模型実験のために土被り圧が小さく, 側方土圧の合力が小さいためであると考えられる.この ような重力場での小型模型実験では, 実際のものとの力 学的相似関係が保証されないことから, 今回の実験では 曲線すべりモードを再現することは困難である. 一方, Kitazume et. al. ${ }^{8)}$ は深層混合処理工法による杭状改良地盤 の支持力特性に関する遠心載荷実験を行っているが, こ れによると改良地盤が曲線すべりにより破壊している. これはフルスケールの重力場が再現された場合, 改良地 盤においてもプランドルやテルツァギーの支持力理論に よる曲線すべりが生じることを示している. 


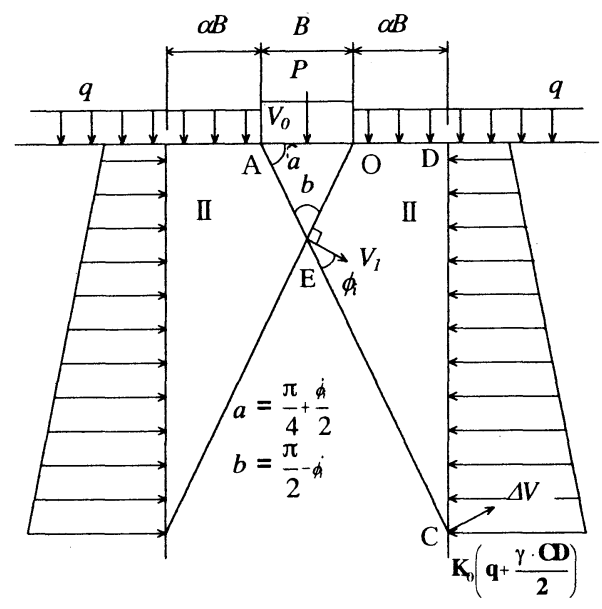

図-9＼cjkstart直線すべりモード

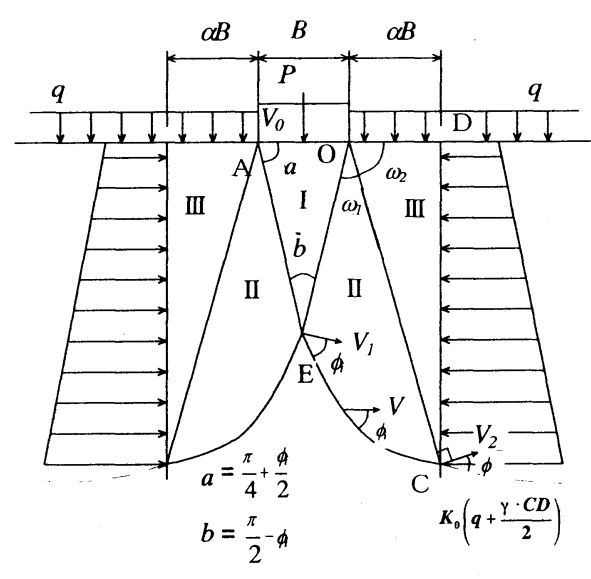

図-10 曲線すべりモード

なお，強度定数については，本文では改良を行わない 砂地盤と改良地盤に対して, 以下のように区別する.

$c_{0}, \phi_{0}, \gamma_{0}:$ 原地般の強度定数

$c_{i}, \phi_{i} \gamma_{i}:$ 改良地盤の強度定数

次に, 内部消散エネルギー $E$ を求める. 全内部消散エ ネルギーE は次式で得られる。

$$
\begin{aligned}
E & =c_{i} \cdot \overline{A C} \cdot V_{1} \cos \phi_{i} \\
& =c_{i} \cdot \frac{(1+\alpha)}{\cos \left(\pi / 4+\phi_{i} / 2\right)} \cdot \frac{B V_{0}}{\cos \left(\pi / 4+\phi_{i} / 2\right)} \cos \phi_{i}
\end{aligned}
$$

次に，全外力仕事 $\Sigma W$ を求める. 外力仕事の総和は, $\mathrm{AO}$ 面に受ける荷重 $P$ による仕事 $W_{p}$, サーチャージ $q$ に よる仕事 $W_{q}, \triangle \mathrm{ACD}$ 領域の地盤自重による仕事 $W_{A C D}$, およびDC面に受ける静止土圧による仕事 $W_{C D}$ の和であ り，それぞれ次式のように表される.

$$
\begin{gathered}
W_{p}=P \cdot V_{0} \\
W_{q}=q \alpha B V_{0} \\
W_{A C D}=\frac{1}{2} \gamma_{i}(1+\alpha)^{2} B^{2} V_{0} \tan \left(\pi / 4+\phi_{i} / 2\right) \\
W_{C D}=-V_{0} B q K_{0}(1+\alpha) \tan ^{2}\left(\pi / 4+\phi_{i} / 2\right) \\
-\frac{1}{2} B^{2} \gamma_{i} K_{0}(1+\alpha)^{2} \tan ^{3}\left(\pi / 4+\phi_{i} / 2\right)
\end{gathered}
$$

全外力仕事 $W_{\text {loal }}$ は式(5)〜(8)を合計して得られる.

$$
W_{\text {total }}=W_{p}+W_{q}+W_{A C D}+W_{C D}
$$

フーチングに作用する荷重 $P$ は, 式(4)と式(9)を等值と して得られる. さらに $K_{0}=1-\sin \phi_{0}\left(\mathrm{Jaky}\right.$ の式 $\left.{ }^{10)}\right)$ と仮定 寸ると式(10)で表される支持力式が得られる. また，内 部消散エネルギーに起因する支持力係数を $N_{c i}$, サ一チャ 一ジに起因する支持力係数を $N_{q}$, 外力仕事に起因する支 
持力係数を $N_{n}$ とすると, これらは式(11)〜(13)のように 表される.

$$
\begin{gathered}
P=c_{i} B N_{c i}+q B N_{q i}+\frac{1}{2} \cdot \gamma_{i}(1+\alpha)^{2} B^{2} N_{r i} \\
N_{c i}=\frac{(1+\alpha) \cos \phi_{i}}{\cos ^{2}\left(\pi / 4+\phi_{i} / 2\right)} \\
N_{q i}=(1+\alpha) \cdot\left(1-\sin \phi_{0}\right) \cdot \tan ^{2}\left(\pi / 4+\phi_{i} / 2\right)-\alpha \\
N_{\gamma_{i}}=\left(1-\sin \phi_{0}\right) \tan ^{3}\left(\pi / 4+\phi_{i} / 2\right)-\tan \left(\pi / 4+\phi_{i} / 2\right)
\end{gathered}
$$

\section{b）曲線すべりモード}

フーチングに荷重 $P$, その周辺地盤に上載圧 $q$ が作用 する状態において，図-10 に示すような可容速度場を考 える. この可容速度場は変位の境界条件と適合条件を満 たす必要があるため, $\mathrm{OE}$ 面と $\mathrm{EC}$ 面における速度の不連 続量に対して, 次の連続条件が成立しなければならない.

OE 面

$$
V_{o}=\frac{\cos \phi_{i}}{\cos \left(\pi / 4-\phi_{i} / 2\right)} V_{1}
$$

$$
\Delta V=V_{1}
$$

EC間

$$
\begin{aligned}
& V=V_{1} \exp \left(\omega \tan \phi_{i}\right) \\
& V_{2}=V_{1} \exp \left(\omega_{1} \tan \phi_{i}\right)
\end{aligned}
$$

次に内部消散エネルギーを求める. 内部消散エネルギー は, 直線すべり区間においては粘着力に速度の不連続量を 乗じて, 遷移領域においてはさらに領域内部での消散エネ ルギーを加えて得られる. 式(16) (18)にそれぞれ OE 間, EC間における内部消散エネルギーを示す.

OE 間

$$
E_{O E}=c_{i} B V_{1} \frac{1}{2 \cos \left(\pi / 4+\phi_{i} / 2\right)}
$$

EC間 $\quad E_{E C}=c_{i} B V_{1} \frac{\exp \left(2 \omega_{1} \tan \phi_{i}\right)-1}{2 \tan \phi_{i} \cos \left(\pi / 4^{+} \phi_{i} / 2\right)}$

$\mathrm{CD}$ 間

$$
\begin{aligned}
E_{C D} & =c_{i} \cdot C D \cdot V_{2} \cos \omega_{2} \\
& =c B V_{1} \alpha \sin \omega_{2} \exp \left(\omega_{1} \tan \phi_{i}\right)
\end{aligned}
$$

また, 全内部消散エネルギー $E_{\text {loal }}$ は, 式(16)〜(18)の和 として得られ, 式(19)のようになる.

$$
E_{\text {total }}=E_{O E}+E_{E C}+E_{C D}
$$

次に外力仕事を求める. 外力仕事は, 外力作用方向の 仕事と地盤自重が重力方向にな寸仕事を合計して得られ る. なおここでは下向きに作用する仕事を正とする.

載荷重 $P$ おびサーチャージによる仕事は次式で表さ
れる.

$$
\begin{gathered}
W_{P}=P V_{1} \frac{\cos \phi_{i}}{\cos \left(\pi / 4-\phi_{i} / 2\right)} \\
W_{q}=-q \alpha B V_{1} \exp \left(\omega_{1} \tan \phi_{i}\right) \cos \omega_{2}
\end{gathered}
$$

I〜III 領域における自重による仕事は次式で表される.

$$
\begin{gathered}
W_{I}=\frac{\gamma_{i} B^{2} V_{1}}{2} \cdot \frac{\cos ^{2} \phi_{i}}{4 \cos ^{2}\left(\pi / 4+\phi_{i} / 2\right) \cos \left(\pi / 4-\phi_{i} / 2\right)} \\
W_{I I}=-\frac{\gamma_{i} B^{2} V_{1}}{2} \cdot \frac{1}{4 \cos ^{2}\left(\pi / 4+\phi_{i} / 2\right)} I
\end{gathered}
$$

$$
\begin{gathered}
I=\frac{1}{9 \tan ^{2} \phi_{i}+1}\left\{\exp \left(3 \omega_{1} \tan \phi_{i}\right) .\right. \\
{\left[3 \tan \phi_{i} \sin \left(3 / 4 \pi-\phi_{i} / 2-\omega_{1}\right)+\cos \left(3 / 4 \pi-\phi_{i} / 2-\omega_{1}\right)\right]} \\
\left.-\left[3 \tan \phi_{i} \sin \left(3 / 4 \pi-\phi_{i} / 2\right)+\cos \left(3 / 4 \pi-\phi_{i} / 2\right)\right]\right\} \\
W_{I I I}=-\frac{\gamma_{i} B^{2} V_{1}}{2} \alpha^{2} \exp \left(\omega_{1} \tan \phi_{i}\right)
\end{gathered}
$$

$\mathrm{CD}$ 間に作用する仕事は次式で表される.

$W_{C D}=-K_{0} V_{1}\left(q+\frac{\gamma_{i} \alpha B \tan \omega_{2}}{2}\right) \exp \left(\omega_{1} \tan \phi_{i}\right) \sin \omega_{2}$

全外力仕事 $W_{\text {boal }}$ は各領域の外力仕事を合計すること で得られ，式(26)のようになる。

$$
W_{\text {total }}=W_{p}+W_{q}+W_{l}+W_{I I}+W_{I I I}+W_{C D}
$$

したがって, フーチングに作用する荷重 $\boldsymbol{P}$ は, 全内部 消散エネルギー $E_{\text {loal }}$ と全外力仕事 $W_{\text {boal }}$ を等值として, 式 (27)で表される. また，内部消散エネルギーに起因する 支持力係数を $N_{i}$, サ一チャージに起因する支持力係数を $N_{q r}$, 外力仕事に起因する支持力倸数を $N_{n}$ とすると，こ れらは式(28)〜(30)のように表される.

$$
P=c_{i} B N_{c i}+q N_{q i}+\frac{\gamma_{i} B^{2}}{2} N_{\gamma i}
$$

$$
\begin{aligned}
N_{c i}= & \frac{\cos \left(\pi / 4-\phi_{i} / 2\right)}{\cos \phi_{i}}\left\{\frac{1}{2 \cos \left(\pi / 4+\phi_{i} / 2\right)}+\frac{\exp \left(2 \omega_{1} \tan \phi_{i}\right)-1}{2 \tan \phi \cos \left(\pi / 4+\phi_{i} / 2\right)}\right. \\
& +\alpha \sin \omega_{2} \exp \left(\omega_{1} \tan \phi_{i}\right)
\end{aligned}
$$




$$
\begin{aligned}
N_{q i}= & \frac{\cos \left(\pi / 4-\phi_{i} / 2\right)}{\cos \phi_{i}} \\
N_{\gamma i}= & \frac{\cos \left(\pi / 4^{-} \phi_{i} / 2\right)}{\cos \phi_{i}}\left\{-\frac{\cos ^{2} \phi_{i}}{4 \cos ^{2}\left(\pi / 4+\phi_{i} / 2\right) \cos \left(\pi / 4-\phi_{i} / 2\right)}\right. \\
& +\frac{\left.I B \cos \omega_{2}+K_{0} \sin \omega_{2}\right)}{4 \cos ^{2}\left(\pi / 4+\phi_{i} / 2\right)}+\alpha^{2} \exp \left(\omega_{1} \tan \phi_{i}\right) \\
& \left.+\frac{K_{o} \alpha}{B} \tan \omega_{2} \sin \omega_{2} \exp \left(\omega_{1} \tan \phi_{i}\right)\right\}
\end{aligned}
$$

(30)

\section{（3）支持力評価式の適用範囲}

図-11 は，支持力実駼結果と提案する支持力式で計算 した理論值の対応を示したものである. 図中, プラスチ ック片混合地盤における矢印は，実際の実際の支持力増 加率が図示されている値よりも大きくなっていることを 示している.

ソイルセメント改良地盤の支持力機構を想定した直線 すべりモードでは， $\alpha<1$ の範用ではほぼ理論值と一致す るが， $\infty 1$ の場合は，実験では支持力改善効果はそれほ ど生じず, 理論値と一致しない.これは次の理由による と考えられる.

直線すべりモードは改良範用の増大に直線的に比例し て支持力は増大寸る. しかし，改良幅が大きくなると曲 線すべりモードにおける内部消散エネルギーが小さくな るため支持力の増大が釷化する. 改良幅比 $\alpha \doteqdot 5$ 程度とな ると，改良された単一の支持地盤とみなしてよく，この 支持力増加率は実験で得られた支持力と同様に 2.6 程度 が上限となる。

一方，改良幅が大きくなると単一地艋に近づくためそ の影響は小さくなり，実験值と曲線すべりモードの理論 值の対応はよくなると考えられる.すなわち，直線す心゙ りモードの適用限界は $\alpha \fallingdotseq 1$ 程度の小さな範井にあると いえる.

プラスチック片混合改良地般の場合，今回の試験では 圾験装置の能力の関係から明確な試験值が出ていないの で理論值との詳細な比較は困難であるが，プラスチック 片混合改良地盤の支持力機構を想定した曲線すべりモ一 ドから得られる理論值よりもかなり大きな改善効果が見 込めそうである.

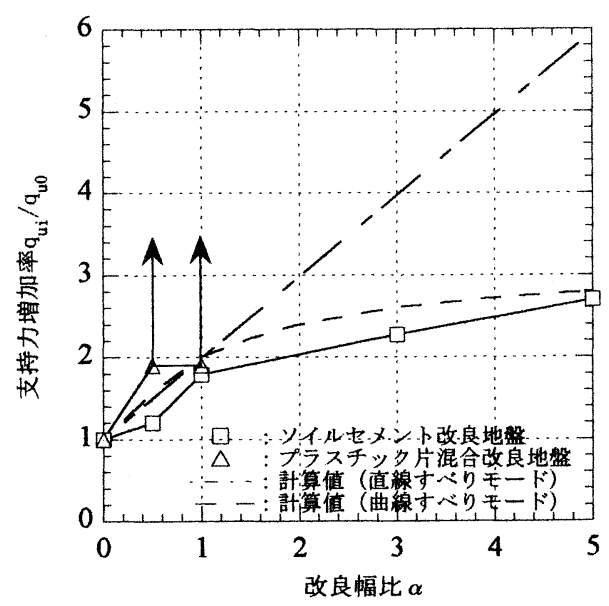

図-11 実験結果と理論值との比較

\section{5. おわりに}

本文では，ソイルセメント改良地艋の支持力改善効果 を室内模型実験により明らかにするとともに，改良地艋 と原地盤の複合地盤に対して,破壊メカニズムを仮定し， 支持力評価式を導いた. その成果は以下のようにまとめ られる.

1）支持力実験用土槽を利用し，試験地盤の作成に種々の 工夫をすることにより，比較的均一なソイルセメント 改良地盤と砂地盤を作成することができた。

2)ソイルセメントのみの改良地盤の荷重一沈下特性とし て，支持力は明確なピーク值を示寸が，その後急激に 支持力が低下するひずみ軟化現象を示す. ただし，こ の場合でも砂地盤のみの場合に比較してはるかに大 きな残留支持力を保持する結果が得られた.

3）ソイルセメント改良地盤にさらにプラスチック片を 追加混合した場合，破壊後のじん性を改善でき，エネ ルギー吸収性能が高まることが明らかとなった。

4）改良地盤の支持力は, 地盤改良幅比 $\alpha$ の増加に伴って 増加する. 特に $\alpha=1.0$ 付近でその増加の程度が大きく なる. また，今回の重力場での破壊形状として直線す ベりが観察された。

5）地盤改良幅が大きくなると改良地盤の単一地盤の支 持力へと近づくものと考えられる. ただし，今回は明 確なすべり線は観察できなかった.

6)二つの破壊メカニズムをもとにした支持力式を提案 し支持力実験結果との対応を考察し，その支持力特性 が改良幅比 $\alpha に$ 応じて, $\alpha<1$ では直線すべりモードに, $\alpha>1$ では曲線すべりモードとなり得ることを示した. 


\section{参考文献}

1) 加藤丈晴, 落合英俊, 安福規之, 大嶺 聖, 大野司郎 : プラ スチック片を混合したセメント安定処理土の改良効果, 九州 大学集報, 第68巻, 第6 号, pp 535-540,1995.11.

2) 築地健太朗, 安福規之, 落合英俊, 大嶺 聖, 宮崎良彦: プ ラスチック廃材を利用したセメント安定処理土の粘り強さ の改善, 第 33 回地盤工学研究発表会講演概要集, pp.2263-2264, 1998.7.

3) 筑地健太朗, 落合英俊, 大嶺 聖, 山本雅之, 宮崎良彦: プ ラスチック片混合によるセメント安定処理土の強度改善効 果, 第 34 回地盤工学研究発表会講演概要集, pp.767-768, 1999.7.

4) 落合英俊, 安福規之, 大嶺 聖, 山本雅之: プラスチック廃 材を用いた新たな地盤材料の活用一表層改良地盤の支持力特 性の改善効果-, 第 3 回環境地盤工学シンポジウム, pp.125-130, 1999.11.
5) 落合英俊, 安福規之, 大嶺 聖, 山本雅之 : プラスチック廃 材を用いた複合地盤材料の開発，土と基礎，第 48 巻，第 6 号, pp.16-18,2000.6.

6) 山本雅之, 落合英俊, 安福規之, 大嶺 聖: プラスチック廃 材の地盤補強材としての有効利用, 第 35 回地盤工学研究発 表会講演概要集, pp.1047-1048, 2000.6.

7) 十河徹, 松本明広，山本英孝: 組及合わせ荷重を受ける杭の 支持力機構に関する研究，九州共立大学卒業論文, 1994,3.

8) Kitazume, M., Ikeda, T. and Miyajima, S. : Bearing capacity of improved ground with column type DMM, Grouting and Deep Mixing, pp 503-508, 1996.

9) 石原研而著 : 土質力学, pp.257-262, 丸善, 1988.

10)落合英俊 : ヤーキーの静止土压係数式，土と基礎，Vol 33， No.4,pp.61-63,1985.

\title{
THE CHARACTERISTICS OF THE BEARING CAPACITY ON THE IMPROVEMENT GROUND WITH MIXED PLASTIC CHIPS
}

\author{
Yasuyuki YOKOTA, Yoshito MAEDA,Hidetoshi OCHIAI and Kiyoshi OMINE
}

This study reveals the characteristics of the bearing capacity of spread foundation on improvement ground of soil cement mixed with plastic chips. First, the unconfined compression test is conducted in order to confirm the improvement of soil cement's elements. Next, the laboratory bearing capacity test is done to clarify the characteristic of the bearing capacity. As the result of these tests, it is found out that, in the case where plastic chips are included, the failure mechanism of the improvement soil cement ground changes from the brittle failure mode to the ductility failure mode. Furthermore, these failure mechanisms are assumed based on the test results, and the equation for evaluating bearing capacity is formulated using the velocity field method. 